Documenta Ophthalmologica 61, 183-189 (1985).

(c) Dr W. Junk Publishers, Dordrecht. Printed in the Netherlands.

\title{
The history of the scientific elucidation of ocular counterrolling
}

\section{H.J. SIMONSZ}

Netherlands Ophthalmic Research Institute, Amsterdam, The Netherlands

The history of the elucidation of ocular counterrolling (OCR) is an interesting one. Although discovered two centuries ago, OCR has remained a controversial issue, even in our days. The main reason for this, is that rolling movements of the eyes about the line of sight are not easily detected or measured. OCR can be static, i.e. about 5 degrees counterrolling of the eyes which partly compensates for tilting of the head with respect to gravity, or it can be dynamic, that is to say a rotatory optokinetic and vestibular nystagmus. The rolling movement of the eyes about the line of sight can be seen when tilting the head of another person towards one of his shoulders. Close inspection of the conjunctival vessels reveals the jerking movements of the quick phase of the rotatory nystagmus.

This is what John Hunter must have seen some two hundred years ago, as he described dynamic OCR in 'The use of the oblique muscles', in a book called 'Observations on certain parts of the animal oeconomy' (1786). His analysis was well ahead of time, for he not only appreciated the role of the oblique muscles in executing these eye movements, but inferred as well, that these rolling eye movements are necessary for maintaining vision while tilting the head (Nagel, 1871). To maintain vision, the eyes must be kept immobile with respect to the surroundings or object that is seen. This is obvious for horizontal and vertical eye movements, but it goes for rolling eye movements too.

Apart from having difficulty in observing OCR, the investigators of the nineteenth century initially confused dynamic and static OCR. A third obstacle was the confusion of rolling eye movements with pseudotorsion. Hueck described rotatory nystagmus in 1838 (Skrebitzky, 1871; Woinow, 1871), but assumed erroneously that OCR compensated for tilting the head up to 28 degrees head-tilt, after which the quick phase of the rotatory nystagmus took place. Donders investigated these claims and denied the existence of OCR completely. How could a genius like Donders be led astray?

Firstly, he looked for the 28 degrees that Rueck had supposedly found. Secondly, he tried to see his own OCR by looking into a mirror attached to a bite-board that he held between his teeth (Nagel, 1871). It is not possible to 
see the jerking movements of your own eyes, however, as vision is suppressed during the quick, jerking phase of the nystagmus. Thirdly, Donders had just devised a law, which von Helmholtz had called Donders' law, that described pseudotorsion. Now pseudotorsion is a subject hard to understand. Pseudotorsion results from describing an eye position by a horizontal and vertical angle, and from describing eye positions on a plane instead of on a globe. Globe geometry is hard to visualize and hence, to simplify matters, a plane is used. The capricious nature of globe geometry can be illustrated by the folflowing example. We wish to describe the eye position 30 degrees right, 30 degrees up. Astonishingly, it makes a lot of difference, whether we first turn 30 degrees right and then 30 degrees up, or first 30 degrees up and then 30 degrees right. Moreover, both mathematical constructions confer a certain amount of pseudotorsion, i.e. a pseudo rolling eye movement, of opposite direction in either way. To circumvent this complication, one can use pole coordinates to describe globe geometry, but that system has disadvantages of its own. Fick $(1854,1858)$ and Donders described eye positions by naming the horizontal angle first, while von Helmholtz described eye positions by naming the vertical angle first (Nagel, 1871).

One can imagine the confusion that existed in those days and this confusion forms the background against which Donders' discrediting of Rueck must be seen. It took another authority, Javal (1866), to re-establish the existence of OCR. He noticed that on head-tilt, the axis of astigmatism of his eyes no longer coincided with the axis of astigmatism of his glasses. Skrebitzky was the guest of Donders in 1869, and Donders, doubting the view he had expressed earlier, asked him to reinvestigate the matter. Skrebitzky (1871) used after-images to measure OCR, which method had been described by Ruete in 1846 (Fisher, 1927). He found $5 \frac{1}{2}$ degrees static OCR on a 45-degree head-tilt. Then Mulder, an assistant of Donders, was asked to study the matter and in 1875 a lengthy treatise on dynamic and static OCR appeared, together with a short article by Donders (1875), containing a description of Donders' law and a revocation of his earlier view on OCR.

By then however, Nagel had already firmly established the existence of static OCR (1871). He made use of his astigmatism, looking at a pattern of 360 radial lines, mounted on a bite-board. The article that Nagel wrote, giving the history of OCR and his findings, seems unsurpassed in clarity and brilliance. It is certainly amazing, that thirty years before the description of the head-tilt test by Hofmann and Bielschowsky in 1900, Nagel predicted the feasibility of such a diagnostic test that relied on OCR. He said: 'Für die feinere Diagnostik der Augenmuskellähmungen wird die Prüfung der bei seitlicher Kopfneigung auftretenden Raddrehung eine willkommene Unterstützung und Vervollständigung sein und namentlich bei den der Analyse zuweilen grosse Schwierigkeiten bietenden kombinirten Augenmuskellähmungen wird sich vermutlich jene leicht auszuführende Prüfung als nützlich erweisen. Ist einer der die Raddrehung vermittelnden Muskeln 
funktionsunfähig, so wird an Stelle derselben eine leichte Ablenkung und ein störendes Doppeltsehen eintreten müssen. Die Doppelbilder werden gegeneinander gedreht erscheinen, zugleich wird ein leichter Seiten- und Höhenabstand statthaben, da dem zweiten bei der Raddrehung betheiligten Muskel das Gegengewicht fehlt, welches die Wirkung auf die Richtung der Blicklinie annulieren sollte. Wahrscheinlich wird die Bewegungsstörung auch gross genug sein, um objectiv erkennbar zu sein.'

Mulder $(1888,1897)$ consequently used perimetry of the blind spot to measure OCR. Barany (1906) measured OCR objectively with a biomicroscope using iris-contours as landmarks. In OCR-measurements, it is important to discern between objective and subjective methods. A subjective method, like the use of after-images, utilizes subjective localisation, i.e. the subjective perception of place in vision. This localisation is dependent upon cerebral circuitry, and as sensory adaptations to cyclodeviations are possible (Guyton and von Noorden, 1978), these data must always be interpreted with care.

Delage (1903) made use of his myopia and astigmatism. The light of a small distant lamp defocused on his retina in the shape of an ellipse. He used the long axis of the ellipse to indicate the rotatory position of the eye. $\mathrm{He}$ had himself strapped to a rotating board and turned 360 degrees. Fisher (1927) used a large box in which the person as a whole, or just the head, could be tilted. Walton (1948) used subjective and objective methods in assessing the axis of astigmatism. Miller et al. $(1962,1970,1971)$ introduced photography of the eye, using iris-contours as landmarks. Howard and Evans (1962, 1964) combined photography of the eye with the bite-board method, that was actually first used by von Helmholz, with episcleral venes as landmarks. This has, beyond doubt, remained the most accurate technique since. Watanabe et al. (1978) used ink-marks at the limbus as reference-points. Petrov and Zenkin (1973) and Galoyan et al. (1976, 1977) used a suction contactlens fitted with a lamp. Jampel (1981) took slitlamp-pictures of the eye after calibration of the position of the slit, in reference to a piece of tape fixed to the skin under the eye. Curiously, he denied the existence of OCR.

Kanzaki (1975, 1978) and Inatomi et al. (1978) introduced infra-red fundus photography and video-imaging. The most promising recent development seems to be computer-analysis of video-images, which will enable OCR to be continuously monitored (Diamond et al., 1982; Hatamian and Anderson, 1983). Another method for continuous registration is the use of a contactlens fitted with a search coil in a magnetic field, which method was devised by Robinson. The lay-out of the coil in the contactlens is altered to the effect that torsion can be measured (Collewijn, personal communication).

Normal values of OCR are somewhat scarce, as large numbers of healthy subjects have rarely been examined. The most reliable data seem to come from the investigation of Nelson and Cope (1971). They used a photography 
method, using iris-contours as landmarks, and a steel frame over the head with a bite-board and supports on the skull and in the meati externi. They found $5.64 \pm 2.57$ degrees on 50 degrees body-tilt $(n=110 ; 35$ right eyes, 20 left eyes, measured both ways). Evidently, there is a considerable interpersonal variance. The difference between yoke eyes in total OCR, in the study of Nelson and Cope, averaged $2.51 \pm 2.28$ degrees, which is a great difference. A third variance occurs in consecutive measurements in one eye of a single person. Diamond et al. (1982) found $1 \frac{1}{2}$ degree spread in a series of 60 photographs taken in 10 minutes. Interestingly, these small rotatory eye movements were not recognizable to the photographer as saccades or nystagmus jerks. Continuous computer-analysis of video-images should bring the answer here.

In considering these variances, it must be borne in mind, that the innervational input of eye muscles has a considerable plasticy. For rotatory eye movements, this principle was emphasized by the demonstration of voluntary torsion by Balliet and Nakayama (1978). Their subjects could perform torsional saccades up to ten degrees either way, at will, after thirty hours of training with after-images. This concept of plasticy is also applicable to the issue of whether postural neck-reflexes take part in effecting OCR or not. Nagel (1871), Mulder (1875), Kompagnejetz (1925), Colenbrander (1964) and Nelson and Cope (1971) all found no difference between head- and body-tilt. Hard evidence is however, that monkeys, after bilateral labyrinthectomy, retain some $25 \%$ of the original OCR on head-tilt (Krejcova e.a., 1971).

This conforms to the findings of Fisher (1927). As stated earlier, he used a box in which the subject as a whole, or just the head, could be tilted. He did a very interesting experiment by tilting the body 40 degrees, but leaving the head upright with respect to gravity. He found 1.4 to 2.4 degrees of OCR. To make it even more interesting, he then tilted body and head together 10 degrees further, and found 0.6 to 1.6 degrees OCR the other way, clearly demonstrating the dominance of the otoliths over the postural neck-reflexes. In our opinion, Fisher's effort to add up otolith OCR and neck-reflex OCR to obtain head-tilt OCR, is just a slight shortcoming in his otherwise excellent work. It seems logical that innervational input from otolith- and neck-reflex are not additive but mainly complementary.

Fisher did quite an amusing experiment to investigate whether the tension in the neck-muscles was of any significance. He had a tightly-fitted helmut made out of plaster, with hooks sticking out on either side. He said it was not easy to keep his head upright with 5 kilograms hanging on one side and we had better believe him. No counterrolling occurred.

Apart from otolith and postural neck-reflex, even more may be at work. Miller et al. (1971) found about 1 degree OCR on body-tilt in 5 deaf subjects with defective labyrinths. He speculates about non-otolith gravireceptors. We might also think of optically induced eye torsion, optostatic counterrolling, 
which may amount to one degree (Mesker, 1953; Crone and Everhard-Halm, 1975).

Another question that deserves mentioning is, which otolith is exciting or inhibiting OCR to which side? Blanks et al. (1978) measured the firing-rate of bulbar, trochlear motoneurons in cats. The rate was proportional to the head-tilt. The innervation was reciprocal with contralateral exciting and ipsilateral inhibiting otolith-projections. However, no consistent pattern of otolith-defects and related OCR abnormalities emerges from the investigations of Barany (1906), Kompagnejetz (1925), Gollas (1936), Nelson and Cope (1971) and Diamond et al. (1982). All agree that OCR is diminished with otolith-defects, especially on head-tilt toward the affected side, but measuring OCR as a diagnostic tool in vestibular disease seems unwarranted.

Electromyographical evidence of the otolith-reflex was given by Scott (1967). Alterations in muscle activity occurred in all four vertically acting muscles. Woellner and Graybiel (1959), Colenbrander (1964) and Young et al. (1981) have measured OCR in persons subjected to abnormal amounts of gravitational acceleration, either by using a centrifuge or in an aeroplane in parabolic flight. In Colenbrander's subject the OCR on 40 degrees tilt increased from 18 to 26 degrees (total), when the gravitational acceleration was increased from $1 \mathrm{G}$ to $2 \mathrm{G}$.

Finally, the experiments in which linear acceleration was used, deserve mentioning. Linear acceleration bypasses the action of the semicircular canals. By excluding the action of the semicircular canals, it is possible to assess the gain and phase-lag of the otolith-reflex, i.e. the reaction-time of the reflex and the effectiveness of the reflex at different levels of reaction-time. Baarsma and Collewijn (1975) applied linear acceleration to rabbits. Lichtenberg et al. (1982) did similar experiments in humans. It was concluded that the otolith-reflex is a slow one. It might be supplementary to the fast semicircular-canal reflex at low frequencies. A similar supplementary role is surmised for the pursuit-system (Blanks et al., 1978; Robinson, 1981).

\section{References}

Baarsma EA and Collewijn H (1975) Eye movements due to linear accelerations in the rabbit. J Physiol 245:227-247

Balliet $\mathrm{R}$ and Nakayama K (1978) Training of voluntary torsion. Invest, Ophthalmoli 17: $303-314$

Barany R (1906) Über die vom Ohrlabyrinth ausgelöste Gegenrollung der Augen bei Normalhörenden, Ohrenkranken und Taubstummen. Arch f Ohrenheilk 68:1-30

Blanks RHI, Anderson JH and Precht W (1978) Response characteristics of semicircular canal and otolith systems in cat. II. Responses of trochlear motoneurons. Exp Brain Res 32:509-528

Colenbrander A (1964) Eye and otoliths. A centrifuge study on the ocular response to otolith stimulation. Aeromed Acta 9:45-91

Crone RA and Everhard-Halm Y (1975) Optically induced eye torsion. II. Optostatic and optokinetic cycloversion. Alb v Graefes Arch Klin Exp Ophth 195:231-239

Delage Y (1903) Sur le mouvements de torsion de l'oeil pendant la rotation de la tête. Ann d'Oculist 130:180-186 
Diamond SG and Markham CH (1981) Binocular counterrolling in humans with unilateral labyrinthectomy and in normal controls. Ann NY Acad Sci 374:69-79

Diamond SG, Markham $\mathrm{CH}$ and Furaya N (1982) Binocular counterrolling during sustained body tilt in normal humans and in a patient with unilateral vestibular nerve section. Ann Otol 91:225-229

Donders FC (1875) Über das Gesetz der Lage der Netzhaut in Beziehung zu der der Blickebene. Alb v Graefes Arch f Ophth 21:125-130

Fick A (1854) Die Bewegungen des menschlichen Auges. Zeitschrift für rationelle Medizin 4:101-128

Fick A (1858) Untersuchungen zur Naturlehre des Menschen und der Thiere. Ed.: J. Molenschott. Vol 5. Heidinger, Frankfurt

Fisher MH (1927) Messende Untersuchungen über die Gegenrollung der Augen und die Lokalisation der Scheinbaren Verticalen bei seitlicher Neigung (des Kopfes, des Stammes und des Gesamtkörpers). Alb y Graefes Arch f Ophth 118:633-680

Fluur E (1975) A comparison between subjective and objective recording of ocular counter-rolling as a result of tilting. Acta Otolaryngol 79:111-114

Galoyan VR, Zenkin GM and Petrov AP (1976) Investigation of the torsional movements of the human eyes. I. Some special aspects of the torsional movements on tilting the head towards the shoulder. Biofizika 21:570-577

Galoyan VR, Zenkin GM and Petrov AP (1977) III. Rapid phase of torsion. Biofizika 22:701-705

Gollas E (1936) Untersuchung der Raddrehung des Augen bei einseitigem Labyrinthausfall. Arch Ohren-Nasen-Kehlkopfheilk 140:340-354

Guyton DL and von Noorden GK (1978) Sensory adaptations to cyclodeviations. Proc Third Meeting Int Strab Assoc, Kyoto; ed: Reinecke RD, Grune and Stratton, New York 339-403

Hatamian M and Anderson DJ (1983) Design considerations for a real-time ocular counterroll instrument. IEEE Trans Biomed Engin 30:278-288

Hofmann FB and Bielschowsky A (1900) Die Verwerthung der Kopfneigung zur Diagnostik von Augenmuskellähmungen aus der Heber-und Senkergruppe. Alb v Graefes Arch f Ophth 51:174-185

Howard IP and Evans JA (1963) The measurement of the eye torsion. Vision Res 3: 447-455

Howard IP and Evans JA (1964) Visually-induced eye torsion and tilt adaptation. Vision Res 4:433-437

Hunter J (1786) The use of the oblique muscles. In: Observations on certain parts of the animal oeconomy. London. Second edition (1792), quoted by Nagel (1871)

Inatomi $\mathrm{A}$, Terao $\mathrm{N}$ and Okamoto $\mathrm{K}$ (1978) Measurement of compensatory cycloduction by fundus photographic method. Proc Third Meeting Int Strab Assoc, Kyoto; ed: Reinecke RD, Grune and Stratton, New York, pp 405-413

Jampel RS (1981) Ocular torsion and the primary retinal meridians. Am J Ophthalmol 91:14-24

Kanzaki J (1975) New device for measurement of ocular countertorsion reflex. Arch Oto-Rhino-Laryngol 211:213-215

Kanzaki J and Ouchi T (1978) Measurement of ocular countertorsion reflex with fundoscopic camera in normal subjects and in patients with inner ear lesions. Arch OtoRhino-Laryngol 218:191-201

Kompanejetz S (1925) On compensatory eye movements in deaf-mutes. Acta Otolaryngol 7:323-334

Kompanejetz S (1928) Investigation on the counterrolling of the eyes in optimum headpositions. Acta Otolaryngol 12:332--350

Krejcova H, Highstein S and Cohen B (1971) Labyrinthe and extra-labyrinthe effects on ocular counter-rolling. Acta Otolaryngol 72:165-171

Kushner BJ and Kraft S (1983) Ocular torsional movements in normal humans. Am J Ophthalmol 95:752-762

Levine MH (1969) Evaluation of the Bielschowsky head-tilt test. Arch Ophthalmol 82: $433-439$

Lichtenberg BK, Young LR and Arrott AP (1982) Human ocular counterrolling induced by varying linear accelerations. Exp Brain Res 48:127-136 
Linwong M and Herman SJ (1971) Cycloduction of the eyes with head tilt. Arch Ophthalmol 85:570-573

Mesker RP (1953) De optische localisatie. Thesis. Swets and Zeitlinger, Amsterdam

Miller EF (1962) Counterrolling of the human eyes produced by head tilt with respect to gravity. Acta Otolaryngol 54:479-501

Miller EF (1970) Evaluation of otolith organ function by means of ocular counterrolling measurements. In: Vestibular function on earth and in space. Ed: Stahle J, Pergamon Press, Oxford and New York

Miller EF and Graybiel A (1971) Effect of gravitoinertial force on ocular counterrolling. J Appl Physiol 31:697-700

Mulder ME (1875) Úber parallele Rollbewegungen der Augen. Alb v Graefes Arch $f$ Ophth 21:68-124

Mulder ME (1888) Ons oordeel over verticaal bij kanteling van het hoofd naar rechts of naar links. Feestbundel Jubileum Donders. Van Rossen, Amsterdam

Mulder ME (1897) De la rotation compensatoire de l'oeil en cas d'inclinaison à droite ou à gauche de la tête. Arch d'Ophthal 17:1-10

Nagel A (1871) Über das Vorkommen van wahren Rollungen des Auges um die Gesichtslinie. Alb v Graefes Arch f Ophth 17:237-264

Nelson JR and Cope D (1971) The otoliths and the ocular countertorsion reflex. Arch Otolaryngol (Stockh) 94:40-50

Nelson JR and House WF (1971) Ocular countertorsion as an indicator of otolith function. Tr Am Acad Ophth Otol 75:1313-1321

Petrov AP and Zenkin GM (1973) Torsional eye movements and constancy of the visual field. Vision Res 13: 2465-2477

Rueck (1938) Die Achsendrehung des Auges. Quoted by Skrebitzky (1871)

Reute (1846) Lehrbuch der Ophthalmologie. Quoted by Fisher (1927)

Scott AB (1967) Extraocular muscles and head tilting. Arch Ophthalmol 78:397-399

Skrebitzky A (1871) Ein Beitrag zur Lehre von den Augenbewegungen. Alb v Graefes Arch f Ophth 17:107-116

Suzuki J, Cohen and Bender MB (1964) Compensatory eye movements induced by vertical semicircular canal stimulation. Exper Neurol 9:137-160

Suzuki J, Tokumasu K and Goto K (1969) Eye movements from single utricular nerve stimulation in the cat. Acta Otolaryngol 68:350-362

Walton WG (1948) Compensatory cyclo-torsion accompanying head tilt. Am J Optom $25: 525-534$

Watanabe Y, Mori R and Ohtsuki H (1978) Studies on the Bielschowsky head tilt test. Proc Third Meeting Int Strab Assoc, Kyoto; Reinecke RD, Grune and Stratton, New York, 387-398

Woellner RC and Graybiel A (1959) Counterrolling of the eyes and its dependence on the magnitude of gravitational or inertial force acting laterally on the body. J Appl Physiol 14:632-634

Woinow M (1871) Beiträge zur Lehre von den Augenbewegungen. Alb v Graefes Arch $f$ Ophth 17:233-240

Young LR, Lichtenberg BK, Arrott AP, Crites TA, Osman CM and Edelman ER (1981) Ocular torsion on earth and in weightlessness. Ann NY Acad Sci 374:80-92 